\title{
Career Management for Educational Organization Success; the Human Resources Perspectives
}

\author{
Obeta Mark Uchejeso $^{1 *}$, Jacqueline Cotton Baguma ${ }^{2}$, Eze Maria Egodi ${ }^{1}$ \\ ${ }^{1}$ Department of Public Administration and Local Government, University of Nigeria Nsukka-Nigeria \\ ${ }^{2}$ Department of Business and Healthcare Management, Arden University, Tower Hill Campus-London
}

DOI: $10.36348 /$ jaep.2020.v04i06.011

| Received: 21.05.2020 | Accepted: 09.06.2020 | Published: 28.06.2020

*Corresponding author: Obeta Mark Uchejeso

Abstract

Career management has come to stay in this era of technological and economic changes in the world, and the way and nature of the career with how people pursue it has changed. Educational organizations therefore, has the need to improve their management so as to achieve better outcome and sustain their continuous competitive advantages over time. Organization assist employees to manage career by establishing different career management programs. Organization may also contribute to career identity by providing abundant opportunities for self-development, advancement and mentoring of their staff to ensure effectiveness and efficiency through career management practices. This paper examines and assess career management practices in educational organizations' effectiveness and efficiency by reviewing literatures and how it can influence the organization by considering strategies, techniques, needs of individuals and needs of an organization towards educational organization success and performance. This paper shall do justice to career management techniques, principles and components of an effective career management and supports given to various staff to develop their career while working in a given organization.

Keywords: Career management, organizational success, education, teacher, human resources.

Copyright @ 2020: This is an open-access article distributed under the terms of the Creative Commons Attribution license which permits unrestricted use, distribution, and reproduction in any medium for non-commercial use (NonCommercial, or CC-BY-NC) provided the original author and sources are credited.

\section{INTRODUCTION}

Career is the job or series of job that someone do during his/her working life especially if he/she continues to get better jobs and earn more money (Cambridge dictionary). Phifer [1] defined career as the party of life that is concern with employment. Career is also the order of jobs of a person in the life time [2]. Career is some total of decisions that direct your educational, social, economic, political and spiritual endeavors and reflect your unique personality characteristics and basic life values. Career refers to a persons' chosen profession or occupation. A career often requires special training and comes with some expectation of progress throughout the course of an individual's life. Career includes all types of employment management ranging from semi-skills through skills, semi-professional to professional, education, training and work experiences.

Career prioritization depends on many factors which determined by their background, age, family situation, financial commitment, lifestyles choices and the future plans. Career is traditionally associated with paid employment and it is referred to a single occupation. In today's world career is seen as a continuous process of learning and development. Activities that contribute to career can include training, education, and employment, work experiences, community activities, enterprises activities employment, different life roles, volunteer work and leisure activities. Career depicts how individuals live their lives across different contexts and settings, including education, family, work and leisure time. However nowadays career includes changes and modifications in employment during the foreseeable future.

Career(s) in education was defined by Watts [3], as that which consist of planned experiences made to facilitate the development of important and paradoxical differences between career(s) education in schools and in higher education which is statutory and based on learning outcomes that is imposed, but is informally assessed and not part of the mainstream curriculum; whereas in higher education it is nonstatutory and based on learning outcomes developed from within, but is often formally assessed and a creditrated part of the curriculum [3]. 
Organization performance in public and private organizations depends on how career management is practiced in the organization. Employees and organizations career management contribute highly to educational organizations success through career management strategies. Most of the literature reviewed based on career management in educational organizations. More findings describe that effective and efficiency career management [4], in modern organizations cannot succeed unless the people they employ agree to contributions that workers will make the firm and vice versa. Popescu [2], while companies pay attention to establishment and implementation of career management programs, individuals can also develop themselves without waiting for career development support from their organizations. In short organizational performance has changed through strategic management of human resource management and make possible the achievement of organization performance [5].

So, the merit given to humans not only increases personal product, but it also lifts up the quality of the company and the team. Human resources with developed talents and creativity, who are able to reach and utilize information, constitute the main power of competition in the world market, [14]. Central to the framework is the idea that effective and lifelong, teacher development depends on teachers taking ownership of their learning and having the capacity to develop and renew their knowledge and skills [7].

Active planning activities were strongly associated with dynamic, open and proactive climates [8]. As such career management has a major development and opportunities offered by an organization find that, their personal aspirations coincide with those of the organization Martin [9]. One of the challenges that organizations are trying to address is the changing nature of the career management, which is required to maintain organization growth Kamudha \& Abraham [10]. Therefore, the success of career management in an organization is determined by collective efforts of an individual and an organization.

\section{Career management}

Career management can be referred as a process by which individuals collect information about interest, values, skills, strengths, weaknesses, identify a career goals and engage in career strategies that increase the possibility that career goals will be achieved [11]. Career management is the capacity to exercise agency and to influence the development of one's own career. Also, career management describes skills, aptitudes, abilities and attitudes of individuals. Career management is balancing the need of the individuals and the needs of organization [9]. Career management is the combination of structured planning and the active management choice of one's own professional career.
The successfulness of the career management should include personal fulfillment, work and work balance, goal achievement, and financial security. Career management remains an ongoing process of preparing, developing, implementing and monitoring career plans and strategies undertaken by the individuals alone or in the concert with the organization career system [12]. Career management are the policies and practices undertaken to ensure that short term, medium- and long-term needs for appropriate member of suitably trained and capable people required by an organization at all level of hierarchy are available internally. Career management describes the knowledge, skills and attributes that an individual need to find and keep work and to manage their career in a way that works for them [13].

Career management can be discussed in two perspectives which are individual career management and organizational career management.

\section{Individual career management}

Career management reflects the developmental practices and process that the person undertakes when seeking to pursue their particular jobs and work preferred overtime. Martin [9] puts it that career management is about balancing the needs of individuals and the needs of an organization. Individual career management, individuals can develop themselves without waiting for career development support from their organizations or institutions. The individuals who focus on occupational goals prefer long term career development and want to be successful in their careers.

Employees who concentrate on career selfmanagement seem to be more proactive than these people who don't take action on their own. From the nature of career and unstable employment there is an increasing idea that individuals' career progression is the responsibility of themselves not the organization's responsibility [11]. This put more emphasis on subjective criteria of career success which including job satisfaction, career satisfaction, work life balance, a sense of personal achievement and training work that is consistent with one's personal values. Due to social, political, economic and technological changes career development has become more critical and impersonal practices.

\section{Organizational career management}

This comprehensive view of organizational career management systems discusses the portfolio of career planning and management practices available in organizations and explores ways by which organizations can use career systems to meet their needs. Organization career management (OCM) refers to the programs or activities provided by organization to supply their employees' career success includes employees' career development. OCM involves techniques such as training and educational opportunities, performance appraisal, career planning 
and monitoring program which help the employee to manage their career and lead them to career satisfaction when provided with the expected programs. OCM provides career development for employee which they can develop competencies that promote employability.

Dargham [14] described OCM as the series of formal and less formal activities designed and managed by the organization to influence the career development of one or more employees and thereby to improve organizational effectiveness. Organization may also contribute to career identity by providing abundant opportunities for self-development, opportunities for advancement and mentors. OCM ensure the long-term availability of skilled and competent employees to reach organization or institution goals. Organizations that rely on formal career planning try to match individual career plans with organizational career management. Career planning is important tool for companies to make sure that employees will have required skills and knowledge when they are needed. Therefore, a variety of organizational career management practices are described in the literature such as employee workshops, job rotation, job enrichment, career progression ladders and like organizationally planned programs or developmental stage theories [14].

\section{Career Management strategies}

The basic model of development is based around the circular and iterative stages of, identifying the need, designing an appropriate development activity to meet the need, carrying out the development, evaluating the outcomes and achievements from the development [9].

Career management has many activities to be performed and programs to be implemented, therefore for the effective career management must involve the following four main activities;

\section{Development of overall goals and objectives}

Career management process begins with setting goals and objectives. Relative specific goals, and objectives should be formed. The entire career management (CM) process is based on the establishment of defined goals and objectives whether specific or general in nature. The utilization of $\mathrm{CM}$ assessment is a critical stage in identify opportunities and career path. These goals and objectives may be categorized into three types as short term that may take 1-3 years, medium term that will be for 3-10 years and long term that will be for more than 10 years. There are variations in the human resource supply and career management policies of organizations [15]. Generally, there may be a 'Grow' or 'Buy' policy or some combination of both.

A 'grow' policy would seek to access, attract and mobilize capable individuals who may be deficient in some ways for meeting the organization's success needs [16], and provide these employees with "training and experience to equip them to assume a level of responsibility compatible with their ability and with practical guidance, encouragement and support so they realize their potential, satisfy their career ambition and wish to remain with the organization" [17].

\section{Development of strategies}

This is the stage where the decision and the selection of the best strategies to reach individual and organizational goals and objectives is done. The means of reaching and the means of accomplishing the goals is determined. Also, goals and the objectives are prioritized.

\section{Development of specific means}

At this stage career management policies are reviewed and the procedures to be followed when one's wished to develop their career and exactly activities that are practiced so as to ensure the career development in an organization regardless it is individual or organization career management.

\section{Systematic evaluation of the progress}

The progress of the achievement of the selected goals and objectives have to be assessed and to make sure that the type of program selected or activities is carried out properly and if not, then some modifications can be made like to change some party of the program or to put more emphasis where it seems insufficient.

\section{The principles that characterize the effective career management}

The chartered Institute of Personnel and Development (CIPD) by Donkins [18] \& King [19] in Martin [9] identifies the number of underlying principles that characterize the effective career management as follows;

\section{Consistency/Consistent}

Career management usually shares the information with human resource professionals and line managers; therefore, the employees take messages and information about their careers in a variety situation which will make them consistent with the organization's perspective picture. Messages about career opportunities and intentions are gleaned by an individual from many sources including their line manager. Consistent information needs to be ensured so that potential opportunities are well known without unrealistic expectations being raised.

\section{Proactivity/Proactive}

Career management is a balancing act that based on a wide range of assumptions. Career management $(\mathrm{CM})$ anticipate the future direction of the individual and an organization and reflects to the wide cooperates strategies and objectives. It maintains the 
current capabilities of the organization and builds flexibility and equality for the future which depends on partnerships between employer and employees.

\section{Dynamism/Dynamic}

The needs of flexibility in career management (CM) practiced and compromised over the career choices to meet the changing needs and expectations of individuals and organization as the circumstances changes which means each party could improve relationship. "in fact, where an organization have active $\mathrm{CM}$ practices in place, can expect the experience reduction in employee turnover, heightened employee motivation, improved employee satisfaction and effective succession in planning" [2]. Successful CM is accomplished through regular habits of building relationships, engaging in career development conversations, updating your career development plan and setting new goals as the life career change.

\section{Collaborative}

In collaboration employer and employees required to work together in achieving the need and expectations of both parties. Both sides must come to consensus on how they can work towards realization of individual and organization goal and objectives. The consensus must be met so as to ensure the efficiency and effectiveness in the organization and the individual to be satisfied with the situation.

\section{The integration of other business and human resource strategies}

Career management actively should be linked to other strategies in order to favors both sides and all employees instead of a chosen for a reason that are not connected with talent, potential, business or organization needs. Also, CM successes if the managers has been seen by employees as taking seriously actions and prepare to provide a meaningful support to them so as to improve their career.

\section{Components of effective career management}

King [19] in Martin [9] suggested a number of components which will comprise the effectiveness of career management. Therefore, the components include both sides, individual and organizational career management.

\section{Career planning}

Career planning that includes the setting of goals and objectives through personal development plan, appraisal and development reviews, development programs and work experiences. Planning applies the concepts of strategic planning and marketing to take charge of one's professional future. "Career planning is the lifelong process which includes choosing an occupation, getting job, possibly changing careers and eventually retiring" [11]. Career planning is an ongoing process whereby individuals set career goals and identifies the means to achieve them. Career planning is helpful for matching organizational objectives and individuals' goals. Organizations should be concerned with career planning because employees' career advancement depends on effective career planning.

\section{Process of career planning}

Process of career planning is sometimes known as career development stages and career development modal. This process helps the employees to plan career and deciding about his/her future. Career planning process involves the following stages;

\section{Self-assessment}

This is the process whereby employees assess their skills, potential, strength, weakness and ability to fulfill their aims. Employees assess themselves and analyze their strength and weakness and draft their future professional and career path they want to choose. In choosing career, more than one career may be considered and only if ones don't satisfy the future the other one can be chosen.

\section{Self-development}

Self-development followed by identification of the quality and skills that required by teacher himself or herself to help them to achieve aims and goals. This might be interested in resources management or in human resources management or other party of his/her teaching career. This also can be also learnt from the courses provided at the university levels where students after assessing his/her strength and weakness then they decide to choose a certain course, example MEMA students at the university of Dares salaam who decided to take their master in education management and administration from a pool of master courses.

\section{A thorough research self-assessment}

The employee does an intensive research on the type of the skills that required in order achieving excellence. Career should ask him/herself the career scope, the future benefits and expansion of the field or an organization in future.

\section{The action form}

After the feasibility of the factors this stage translates and put plans and chooses the best way to achieve and come up with the action plan. The setting of small goals will leads to the success of the main goal and objective and acts as the path way to the main aim.

\section{Action implementation}

After all procedures have been done the career keep every track of his/her activities to make sure that the track acts as the pathway and surely, they are going to help them to achieve their goals. At this stage is where all strategies, plans and resources are going to be implemented for organization or individuals to find the successful way to both individual and organization goals and objectives. The starting point for any development activity is to identify the need that it is intended to fulfil. 
There can be many such triggers for development but they can be generally categorized under one of three headings, Firstly is a gap that means if there has been a gap or deficiency identified in relation to what the organisation, department, team or individual can do relative to what is currently (or anticipated to be) required. Secondly the problem that has arisen and that a possible training intervention could resolve it. And lastly the need aligned with the longer-term direction and intentions of the organisation than the previous over the long term [9].

\section{Provision of Career support}

Career support is offered by a range of different mechanisms in an organization. This is provided through networking that existing in relationship to management. The following are types of career support;

\section{Career information}

Career information describes the information that supports career and learning choices. That information may report on labor market, such as salary of various professions, employment rate in various professional, available training programs and current job opening. "Good quality career information is essential for good quality career development. It includes information on education and training opportunities, occupation and their characteristics and labor market "supply and demand" [20]. This help employees to identify their unique interests, personality, values and skills to determine how well they may match with a certain career.

\section{Career counselling}

"Career counselling is the activity that integrates the different stapes in the career planning process. Career counselling may be done by an employee line manager or immediate manager, human resource specialist or combination of two and outsides consultants" [21]. Counselor assess the needs, interest, personality values and skills so as to help the individuals to explore career options. In the organizational context counseling would be likely to be available as a party of employee assistance programs with open and free access to employee.

\section{Career Pathing}

Career pathing is technique that addresses the specific of progressing from one job to another in the organization. define career pathing as "a sequence of developmental activities involving informal and formal education, training and job experiences that help an individual's capable of holding more advanced jobs", [21]. The most career path practiced is upward mobility in a single occupation example the teachers who are upgrading themselves from certificate to diploma and degrees are practicing this form of mobility.

\section{Mentoring}

Mentoring is generally considered to be based on a long-term relationship. Often it involves a more senior individual passing on advice and guidance, giving the junior partner the benefit of their greater understanding, knowledge and experience [9]. Therefore CIPD [22] identified the main characteristics of mentoring as, a supportive form of development, a focus on helping an individual to progress their career and improve their skill base, Personal issues and difficulties being integrated into the mentoring relationship process more effectively than in coaching with its focus on performance development and having personal as well as organisational objectives and benefits.

"For example, when a change in curriculum introduces a new teaching topic, teachers may be observed by new teachers, so these can learn from more experienced colleagues; by senior teachers, for mentoring purposes; or by the school principal, for monitoring or to provide constructive development assistance" [23]. "It will also support the priority of ensuring the quality of teachers entering the profession, supporting their induction and mentoring, and supporting the continuing educational needs have experienced teachers" [24]. Methods needed to develop employees involve on-the-job and off-the-job learning. On-the-job learning could include job instructions, apprenticeship, coaching and mentoring, job rotation, job enrichment or job enlargement, opportunities to apply learned skills, and committee assignments [6].

\section{Career management skills (CMS)}

Career management skills include the skills of understanding one's own strengths and weaknesses, needs and wants of being able to identify relevant opportunities and access information on them. "Career management skills is the term used to describe the skills, attributes, attitudes and knowledge that individuals require in order to manage their career", [25]. "Career management skills are competencies which help the individuals or organization to identify their existing skills and develop career goals and take action to enhance their careers" [26].

\section{Career management in education and the success towards the educational organizations}

The quality of human resources of an organization is essential to its success. Each organization must seek to improve the quality of its workforce. The importance of career management can only be appreciated with a clear understanding of its direct impact on employee's performance as an improvement in employee's performance lead to an improvement in an organization performance.

"Therefore, developing the desired knowledge, skills and abilities of the employees to perform well their tasks and the duties is of important and requires 
effective programs that may also effect employee motivation and commitment to job", [27]. The expectation of moving up an organization hierarchy through promotion and obtaining beneficial career management, experiences increasing an teachers' morale and motivation of strong involvement in an organization accompanied by job effectiveness, increased job attendance and great willingness to remain with an organization or school. "Development of the people, their competencies and the process of development of the total organization are the main concerns of human resources management", [28].

"Career development is a great importance to both teachers and the school organization" [29]. Tanzania standing order for public service in Tanzania [27] states that it is the government policy that, Tanzania should self-sufficient in trained and skilled human resources to manage its economy and systematic approach should be applied to organizations to build a human capital capable of delivering the services fit to the expectation of the citizens. This means the process should be applied even in educational organizations so as to ensure the efficiency and effectiveness in an organization. Some of the problems related to career management of academic staff at higher education institutions related to the static nature of the job, lack of training possibilities, insufficient evaluation schemes, lack of incentives and schemes to motivate staff to improve their skills level and develop further, [25].

In Tanzania in most school organizations and institutions there is no schedule or time to when and how teachers or administrators are expected to attain a certain course for upgrading their skills and competences. The skills upgrading that is currently taking place is based on individuals' effort and it is not geared towards addressing identified needs of practicing teachers [30]. When teachers supported to learn and develop their skills, they would be sufficiently motivated to give their best to ensuring the continuous growth and successful performance of the school organizations as they work in the means of career planning resources including communication, workshops, career counselling etc. "In providing this programs organizations seem to recognize deficiencies among employees and the needs for continuous learning to remedy these", [16].

Therefore "through the programs, employee (teachers) develop new skills and capabilities which not only enable them to cope with changes in the environment but also motivate their commitment thus improving organizations overall performance", [31,16].

\section{Effective career management Indicators in education}

When the career management positively affecting individuals and organizations goals simultaneously by balancing them, the following indicator will be alarming in educational organizations

(i) High number of committed and motivated teachers and administrators.

(ii) High level of teacher's retention in school organizations and institutions.

(iii) Raised level of productivity example students' academic performance, cooperation and respect within organizations.

(iv) Improved teacher and students/pupils' behaviors and discipline.

(v) Positive reputation among actual and potential teachers.

(vi) Human capital development and improved level of employability throughout teacher's life.

\section{CONCLUSION}

Career management is the key to accomplish both individual and organization goals with well understanding the career management skills. Many organisation consider career management as an important to contemporary human resources management practices and they assist employees to manage career. Career management describes the active and purposeful management career by an individual throughout the lifetime especially those related to that person's occupations. Often composed of the job held, titles earned, and work accomplished over a period of time rather than just referring to one position.

Sometimes career includes education, training, paid and unpaid work, family, volunteer work, leisure activities and more. Career has been restricted to an employment commitment to a single trade skills, profession or business firm for the entire working life of a person. The successfulness of the career management should include personal fulfillment, work and work balance, goal achievement and financial security. The process of career management allows employees predicting their future career and for an organization it ensures that it will have human resources prepared to take vacancies, [32]. All educational organizations and institutions should practice career management for their successfulness as it buttresses the human resources perspectives of any organisation.

\section{Data Availability Statement}

The data that support the findings of this study are available on request from the corresponding author. The data are not publicly available due to restrictions.

\section{REFFERENCE}

1. Phifer, P. (2003). College majors and careers 5th edition. New York, NY: Furguson Publication.

2. Popescu, O. R. (2015). Career management na human resource. Discoursecof form of multiculturalism in literature and communication section:sociology, political science and international relations, 181-189. 
Obeta Mark Uchejeso et al; J Adv Educ Philos, June, 2020; 4(6): 306-312

3. Watts, A. G. (2016). Careeer development learning and employability:The higher academy leaning and employability.

4. Wangithi, W. E., \& Muceke, N. J. (2012). Effective of human resource management practices on psychological contract in organizations. International Journal of business and social science, 3(19); 117-122.

5. CANIA, L. (2014). The impact of strategic human resource management on organizational performace. Economic sera management, 17(2) 373-383.

6. Burke \& Hutchins. (2008) and Kulkarni. (2013) in Khan, S. A., Rajasekar, J \& Al-Asfour, A. (2015). Organizational career development practices: Learning from an Oman Company, Intrnational Journal of business and management, 10(9) 89-98 http://dx.doi.org/10.5539/ijbm.v10n9p88.

7. Hammond, L \& Rothman, R editors. (2011). Teacher and leader effectiveness in high-performig education systems. washington DC: Allience for excellent education and stanford press.

8. Baruch, Y., \& Peiperl, M. (2000). Career management practices:an empirical survey and implications. Human resource management, 39(4) 347-366.

9. Martin, J. (2010). Key concept in human resource management. London ECIY-1SP: Sage publiblicatio Ltd.

10. Kamudha. A \& Abraham. S. (2008). Organization career management and its impact on career satisfaction:A study in the Banking sector. ResearchGate, 48-58.

11. Patrick, H. A., \& Kumar. A. (2011). Career management, employee development and performance in India information technology organizations. Business management dynamics, 1(5) 24-31.

12. Adekola, B. (2011). Career planning and career management as correlated for career development and job satisfaction: A case study of Nigeria Bank employees. Australian Journal of business and management research, 100-112.

13. Hooney, J., Watts, A. G., \& Andrews, D. (2015). Teachers and careers: The role of shool teachers in delivering career and employability learning:International centre for guidance studies, Derby:University of Derby.

14. Dargham, A. (N Y). The organizatioal career magement and career behaviour. N N, 1-14.

15. Amstrong, M. (2001). A handbook of human resource management practice, (8th ed). London:kogan page

16. Nwuche, C. A., \& Awa. H. (2011). Career planning and development:The realites in Nagerian organizations. International business and management, 2(2) 117-129.

17. Mullins, L. (1995). Management and organizational behavior (3rd eds), London: Pitman.

18. Donkin, R. (2002). The future of career. London: CIPD Publisheng.

19. King, A. D., Pržulj, N., \& Jurisica, I. (2004). Protein complex prediction via cost-based clustering. Bioinformatics, 20(17), 3013-3020.

20. OECD. (2002). Organizatioanal for economic cooperation and development. In OECD, Rethinking human capital in education policy analysis. Paris: OECD.

21. Sims, R. (2002). Organizational success through effective human resource management. USA: Greenwood publishing group inc.

22. CIPD. (2008). Data protection, Factsheet, Available at http://www.cipd.co.uk.

23. OECD. (2011). Biulding a higher-quality teaching profession:Lessorn from around the world. Paris: UNESCO.

24. Ministerial council on education employment training and youth affairs. (2003). A national framework ofr profession standards for teaching, Carlton-Australia, Curriculum cooperation and youth affairs (MCEETYA).

25. Budapest, F. D., \& Brussels. M. (2012). Human resource management in Public higher education in TEMPUS partner Countries. Brussels: Brussels TEMPUS Press.

26. Neary, S., Dodd, V., \& Hooley. (2016, april 9th). Understanding career management skills: Findings from the first phase of the career management skills leader project. Retrieved from hdl.handle.net: http://hdl.handle.net/10545/595866

27. Meyer, D.T \& Allen. J. (2009). Management training. London: the cromwell Press.

28. Pareek. U \& Rao, T. V. (1992). Designing and managing human resource systems. Delhi: Oxford \& IBH Publishing Company.

29. Amstrong, M. (2008). Strategic human resource management:A guide action. India: Replika Press Ltd.

30. MoEVT., \& UNESCO. (2014). Enhancing teachers education for bringinging the education quality gap in Africa:The case of tanzania. Dar es Salaam: UNESCO.

31. Woodd, M. (1997). Human resource specialistsguardians of ethical conduct?. Journal of European Industrial Training.

32. Tubutiene, V \& kolaityte, J. (2009). Interaction of an organization and an employee in career management:a case study of S'iauliai University. Ekonomika ir vadyba:aktualijos ir perspektyvos, 1(14) 301-313. 